\title{
SINERGI PEMERINTAH DAN PERUSAHAAN PADA AKTIVITAS CSR DALAM RANGKA MENGHADAPI MEA
}

\author{
Kokom Komariah, Evi Novianti, Hanny Hafiar, dan FX. Ari Agung Prastowo \\ Program Studi Humas Fakultas Ilmu Komunikasi \\ Universitas Padjadjaran \\ Email: kokom.komariah66@yahoo.com dan hannyhafiar@gmail.com,
}

\begin{abstract}
Corporate Social Responsibility activities ideally be felt by the West Bandung Regency, where The West Bandung Regency has now transformed into an industrial area. This change of course, like the two-edged sword, the meaning is the presence of the company is actually able to provide changes in the economy for local communities, in an effort to prepare for the MEA, but on the other hand an industrial presence in West Bandung Regency giving new homework in terms of environmental management and the company's contribution to increasing local revenues of West Bandung regency. Whereas CSR is expected to become one of the company's contributions to improving the competitiveness of West Bandung Regency society. In other words, the company's contribution through Corporate Social Responsibility activities, become the hope of West Bandung regency government in building the human resources of competitive and independent and prosperous. Therefore, this study aims to dig deeper into the synergy of government and companies on CSR activities in order to face the MEA. This research is using qualitative descriptive method through data collection techniques of interviewing and observation. The results of this research indicate that in practice between the government and companies there are communication problems, therefore it is necessary to build appropriate communication models between the government and the companies as well as the community called tripartite corporate social responsibility so that corporate social responsibility activities better planned, targeted and sustainable.
\end{abstract}

Keywords: Company; CSR; Government; Synergy.

\begin{abstract}
ABSTRAK
Aktivitas Corporate Social Responsibility (CSR), idealnya di rasakan oleh Kabupaten Bandung Barat, dimana Kabupaten Bandung Barat saat ini telah bertransformasi menjadi daerah industri, perubahan ini tentunya bagaikan dua mata sisi pedang, Maksudnya kehadiran-kehadiran perusahaan sejatinya mampu memberikan perubahan secara ekonomi bagi masyarakat sekitar, sebagai upaya mempersiapkan diri menghadapi Masyarakat Ekonomi ASEAN (MEA), tetapi disisi lain kehadiran industri di Kabupaten Bandung Barat memberikan pekerjaan rumah baru dalam hal pengelolaan lingkungan serta kontribusi perusahaan dalam peningkatan pendapatan asli daerah Kabupaten Bandung Barat. Padahal CSR diharapkan menjadi salah satu bentuk kontribusi perusahaan dalam meningkatkan daya saing masyarakat Bandung Barat. Dengan kata lain, kontribusi perusahaan melalui aktivitas CSR menjadi harapan pemerintah Kabupaten Bandung Barat dalam membangun sumber daya manusia yang berdaya saing dan mandiri serta sejahtera. Oleh karena itu penelitian ini bertujuan untuk menggali lebih dalam mengenai sinergi pemerintah dan perusahaan pada aktivitas CSR dalam rangka menghadapi MEA. Penelitian menggunakan metode deskriptif kualitatif melalui teknik pengumpulan data wawancara dan observasi. Adapun hasil dari riset ini menunjukkan bahwa dalam pelaksanaannya antara pemerintah dan perusahaan masih terdapat kendala komunikasi. Komunikasi menjadi titik perhatian bagi tim Forum CSR di Kabupaten Bandung Barat, hal ini dikarenakan ditemukan beberapa persoalan terkait implementasi
\end{abstract}


aktivitas CSR. Oleh karena itu, perlu dibangun model komunikasi yang tepat antara pemerintah dan perusahaan serta masyarakat yang disebut dengan tripartit CSR, sehingga aktivitas CSR lebih terencana, tepat sasaran, dan berkelanjutan.

Kata kunci: CSR; Pemerintah; Perusahaan; Sinergi.

\section{PENGANTAR}

Corporate social responsibility (CSR) merupakan isu dinamis yang sangat relevan dalam konteks ASEAN dan Masyarakat Ekonomi ASEAN (MEA). Isu CSR menjadi penting terutama dalam kaitannya dengan social justice rights. Hal ini dikemukakan oleh Nurul Isnaeni (2015), selaku peneliti dari Departemen Ilmu Hubungan Internasional FISIP UI di Indonesia. Pernyataan tersebut selaras dengan pendapat Yulianita (2005), yang menyatakan bahwa aktivitas corporate social responsibility menjadi salah satu kewajiban yang harus dilaksanakan oleh perusahaan sesuai dengan isi pasal 74 Undang-Undang Perseroan Terbatas yang telah disahkan oleh Dewan Perwakilan Rakyat pada juli 2007. Hal ini menunjukan bahwa CSR dipahami sebagai suatu wahana yang dapat dipergunakan untuk mencapai tujuan pembangunan masyarakat yang berkelanjutan, dengan harapan bahwa aktivitas CSR dapat memenuhi kepentingan stakeholder, baik yang di dalam maupun yang di luar perusahaan.

Aktivitas CSR yang banyak dilakukan perusahaan adalah komitmen bisnis untuk berkontribusi kepada ekonomi pembangunan berkelanjutan, bekerja dengan pegawai, keluarganya, komunitas lokal, dan masyarakat untuk meningkatkan kualitas hidup masyarakat, terlebih di era MEA. Pemikiran tersebut senada dengan pernyataan dari Sudaryoko (2015), sebagai Manager Community Development PT. Pertamina Hulu Energi, yang menyatakan bahwa "dalam menghadapi pasar bebas MEA, harus memiliki sumber daya manusia yang profesional dan tangguh untuk bersaing dengan tenaga luar negeri".

Sesungguhnya, CSR yang menjadi 'zakatnya' sebuah perusahaan. Kegiatan CSR, ternyata tidak cukup hanya dilakukan oleh perusahaan, tetapi sebaiknya informasi kegiatan tersebut disebarluaskan kepada masyarakat. Contohnya, perusahaan mengiklankan CSR dalam bentuk advertorial, baik melalui media massa cetak maupun elektronik untuk menunjukkan tanggung jawab terhadap komunitas atau publik terkait, baik publik internal (karyawan), maupun publik eksternal.

Corporate Social Responsibility adalah komitmen perusahaan atau dunia bisnis untuk berkontribusi dalam pengembangan ekonomi yang berkelanjutan dengan memperhatikan tanggung jawab sosial perusahaan dengan menitikberatkan pada keseimbangan antara perhatian terhadap aspek ekonomi, sosial, serta lingkungan. Kompleksitas CSR yang semakin rumit dalam dekade terakhir terkait implementasi yang terdesentralisasi telah menempatkan CSR sebagai suatu konsep yang diharapkan mampu memberikan alternatif terobosan baru dalam pemberdayaan masyarakat miskin (Untung, 2008). Hal ini sejalan dengan pernyataan Chair of Asean CSR Network sekaligus sebagai Executive Director Indonesia Business Links Yanti Triwardiantini (2015), yang mengatakan bahwa program Corporate Social Responsibility (CSR) menjadi salah satu kendaraan untuk menuju bisnis yang bersifat responsible dan sustainablility.

Menurut Iriantara (2004), dalam Wiwitan, Trigartanti, Hernawati (2008), CSR atau tanggungjawab sosial korporat selama ini selalu identik dengan usaha-usaha besar. Padahal, tanggungjawab ini melekat pada semua kegiatan usaha tanpa memandang ukurannya. Bahkan, usaha kecil dan menengah sekalipun memikul tanggung jawab sosial tersebut. Hal ini merupakan konsekuensi dari kenyataan bahwa lembaga atau organisasi selain berdimensi ekonomi juga berdimensi sebagai institusi sosial.

Perusahaan dalam melaksanakan kegiatannya tidak lagi hanya memanfaatkan keuntungan untuk kepentingan manajemen dan investor semata. Perusahaan juga perlu untuk memikirkan konsumen yang telah membeli produk mereka dan masyarakat sekitar perusahaan, baik yang secara langsung maupun tidak langsung terkena dampak dari munculnya perusahaan. Begitu juga karyawan yang merupakan bagian utama 
perusahaan. Perusahaan diharapakan mampu untuk memberikan bantuan kepada publik internal dan publik eksternal dari sebagian keuntungan perusahaan tiap tahunnya, yang disebut dengan CSR. Definisi Corporate Social Responsibility menurut World Bank adalah:

The Commitment of business to contribute to sustainable economic development working with employees and their representatives the local community and society at large to improve quality of life, in ways that are both good for business and good for development"(Wibisono, 2007).

The World Business Council for Sustainable Development dalam Kotler dan Lee (2005) mendefinisikan CSR sebagai: "Business commitment to contribute to sustainable economic development, working with employees, their families the local community, and society at large to improve their quality of life". Sementara Kotler dan Lee (2005) memiliki definisi sendiri untuk CSR yakni sebagai berikut: "Corporate Social Responsibility is a commitment to improve community well-being through discretionary business practice and contributions of corporate resources".

Delapan isu krusial kegiatan CSR di negaranegara sedang berkembang adalah mengatasi kemiskinan dan kelaparan, pendidikan dasar, kesetaraan gender, dan pemberdayaan perempuan, kematian anak, kesehatan ibu, HIV/AIDS, malaria, dan penyakit menular lainnya, menjamin keberlanjutan lingkungan, dan kemitraan global dalam pembangunan. Sementara itu, komponen program CSR yang didanai oleh kebanyakan perusahaan adalah (1) komponen sosial (diadakan sesuai dengan kebutuhan dan kesepakatan kelompok sasaran), (2) komponen ekonomi (kredit mikro/ revolving fund, modal investasi sistem, dan integrated framing system/sistem pembingkaian terpadu), (3) komponen infrastruktur/lingkungan (perawatan, perbaikan, dan pembangunan sarana serta prasarana dasar lingkungan, termasuk pelestarian lingkungan sesuai dengan kebutuhan komunitas), (4) charity/sumbangan versus empowerment/ pemberdayaan menghadapi self reliance/ keswadayaan) (Susanto, 2009).
Aktivitas CSR idealnya di rasakan oleh masyarakat di Kabupaten Bandung Barat, karena Kabupaten Bandung Barat saat ini telah bertransformasi menjadi daerah industri. Perubahan ini tentunya bagaikan dua mata sisi pedang, maksudnya adalah kehadirankehadiran perusahaan sejatinya mampu memberikan perubahan secara ekonomi bagi masyarakat sekitar, tetapi di sisi lain kehadiran industri di Kabupaten Bandung Barat memberikan pekerjaan rumah baru dalam hal pengelolaan lingkungan serta kontribusi perusahaan dalam peningkatan pendapatan asli daerah Kabupaten Bandung Barat. Hal ini senada dengan pemikiran bahwa: dalam prakteknya, banyak kegiatan pemberdayaan masyarakat belum sesuai dengan konsep pemberdayaan masyarakat (Indrawati, Awang, Faida, \& Maryudi, 2016). Tidak kalah penting adalah kontribusi perusahaan dalam meningkatkan daya saing masyarakat Bandung Barat. Dengan kata lain, kontribusi perusahaan melaui aktivitas CSR menjadi harapan pemerintah Kabupaten Bandung Barat dalam membangun sumber daya manusia yang berdaya saing dan mandiri serta sejahtera. Realitanya ternyata aktivitas CSR di Kabupaten Bandung Barat menurut penuturan Kepala Dinas Sosial Tenaga Kerja dan Transmigrasi Kabupaten Bandung Barat, Heri Partomo yang dikutip oleh Harian Umum Pikiran Rakyat menyatakan bahwa:

Sejumlah perusahaan di Kabupaten Bandung Barat dinilai belum terbuka soal pelaksanaan Program Tanggung Jawab Sosial Perusahaan (CSR). Sebab, Pemerintah daerah tidak menerima banyak laporan soal program CSR tersebut. Partomo menambahkan sejumlah perusahaan kerap beranggapan program CSR telah dilakukan ketika memberi dana terhadap kegiatan yang diajukan masyarakat. Padahal, dana CSR semestinya terlebih dulu disalurkan kepada Pemkab Bandung Barat melalui Badan CSR Bandung Barat. Dengan demikian, pemerintah dapat mengetahui laporan CSR dari setiap perusahaan. Program CSR nantinya digunakan untuk lingkungan, pendidikan, kesehatan, dan program sosial lainnya di masyarakat,". Meski tidak menyebutkan jumlah perusahaan di KBB yang telah wajib mengeluarkan dana CSR nya, Heri mengungkapkan, perusahaan di KBB saat ini tercatat ada 724 perusahaan 
dari mulai perusahaan kecil, sedang, menengah dan besar. Dari jumlah itu, diakuinya, dirinya belum mengetahui berapa perusahaan yang telah menyalurkan dana CSR -nya.

Hal yang menarik dari aktivitas CSR di Kabupaten Bandung Barat adalah telah terbentuknya Forum perwakilan perusahaan perusahaan yang ada di Kabupaten Bandung Barat dan pejabat dari Satuan Kerja Perangkat Daerah (SKPD) yang disebut Forum Bandung Barat Corporate responsibility (FBBCSR). Latar belakang adanya FBBCSR adalah membangun sinergi (keterpaduan) antara pemerintah daerah dan perusahaan yang ada di KBB untuk membantu masyarakat miskin secara tepat sasaran dan dapat dipertanggung jawabkan sehingga dengan adanya FBBCSR ini pembangunan kesejahteraan dilaksanakan secara berkelanjutan. Kabupaten Bandung adalah kabupaten yang relatif muda namun memiliki semangat tinggi membangun ekonomi, terlihat dari perkembangan pencapaian pembangunan sampai akhir tahun ini. FBBCSR merupakan lembaga khusus yang terdiri dari perwakilan perusahaan, akademisi dan pemerintah. Kegiatan dari forum ini difokuskan kepada kegiatan penyediaan air bersih, sarana pendidikan, beasiswa sarana kesehatan rumah ibadah, infrastruktur, dan pembangunan kapasitas meliputi pendidikan wirausaha dan pemberian modal usaha dalam forum ini dana yang sudah dikelola sebesar 1.26 milyar.

Pemberian dana kepada masyarakat dari sebagian keuntungan perusahaan tiap tahunnya tidak menjadi solusi yang tepat, karena dana yang diberikan banyak yang tidak dimanfaatkan dengan efektif dan efisien, sehingga tanggung jawab perusahaan kemudian menjadi semakin kompleks. Moore (2000), menyatakan bahwa sumbangan perusahaan merupakan pernyataan falsafah manajemen yang memberikan keuntungan pertama kepada manusia dalam melaksanakan suatu bisnis. Pelaksanaan kegiatan CSR tidak hanya dengan memberikan dana secara langsung, tetapi dana tersebut dapat dikelola perusahaan yang kemudian mengadakan pelatihan untuk meningkatkan pendidikan ataupun pengadaan pemeriksaan kesehatan keliling dengan dana tersebut. Sebagaimana pernyataan Moore (2000), bahwa perusahaan mempunyai tanggung jawab sosial guna meningkatkan kesejahteraan, kesehatan, pendidikan, dan kehidupan kemasyarakatan, serta kebudayaan. Sebuah perusahaan dagang publik mempunyai tanggung jawab sosial sebagai berikut:

(1) Menyediakan sumber lapangan kerja, dengan komitmen nyata pada diversitas dalam perekrutan, promosi karir, dan gaji karyawan di semua level. (2) Beroperasi untuk mendapat profit dan memberikan pendapat yang masuk akal (reasonable) bagi shareholder-nya. (3) Menyusun dan memenuhi sasaran strategis yang memberikan pertumbuhan dan daya saing jangka panjang. (4) Patuh atau menuruti aturan pemerintah berkenaan dengan aturan keamanan, kesehatan, dan lingkungan kerja. (5) Menyisihkan sebagian pendapatan per tahun untuk tujuan filantropi (amal). (6) Mempertahankan standar operasi yang sama di setiap negara di mana perusahaan menjalankan bisnisnya. (7) Berpartisipasi aktif dalam proses kebijakan publik yang mempengaruhi perusahaan, industrinya, dan stakeholder lain yang merupakan bagian dari "kepentingan publik". (Cutlip, Center, Broom, 2006).

Kegiatan Corporate Social Resposibility mengalami perubahan yang disebabkan oleh perubahan peraturan, kepentingan masyarakat yang semakin kompleks, dan kepentingan perusahaan itu sendiri. Menurut Wibisono (2007):

"Implementasi Corporate Social Resposibility di perusahaan pada umumnya dipengaruhi oleh beberapa faktor. Pertama, adalah terkait dengan komitmen pimpinannya. Perusahaan yang pimpinannya tidak tanggap dengan masalah sosial, jangan diharapkan akan mempedulikan aktivitas sosial. Kedua, menyangkut ukuran dan kematangan perusahaan. Perusahaan besar dan mapan lebih mempunyai potensi memberi kontribusi ketimbang perusahaan kecil dan belum mapan. Ketiga, regulasi dan sistem perpajakan yang diatur pemerintah. Semakin amburadul regulasi dan penataan pajak akan membuat semakin kecil ketertarikan perusahaan untuk memberikan donasi dan sumbangan sosial kepada masyarakat".

Sebaliknya semakin kondusif regulasi atau semakin besar intesif pajak yang diberikan, akan lebih berpotensi memberi semangat 
kepada perusahaan untuk berkontribusi kepada masyarakat. Oleh karena itu, penelitian mengenai sinergi pemerintah dan perusahaan di Kabupaten Bandung Barat pada kegiatan Corporate Social Responsibility, akan menguraikan identifikasi masalah berupa bagaimana bentuk sinergi yang terbangun antara pemerintah dengan perusahaan serta kendala atau hambatan yang dihadapi untuk membangun sinergitas tersebut.

Artikel ini adalah deskriptif kualitatif yang memaparkan secara detail hasil penelusuran mengenai tema yang diteliti. Menurut Isaac dan Michael dalam Witri (2008), metode deskriptif dapat melukiskan atau menggambarkan secara sistematis fakta atau karakteristik populasi tertentu atau bidang tertentu secara faktual dan cermat. Penelitian deskriptif kualitatif bertujuan untuk mendapatkan gambaran yang menyeluruh dan mendalam berdasarkan situasi alami dari pelaksanaan program CSR di Kabupaten Bandung Barat. Penulis menganggap metode yang paling sesuai dengan penelitian ini adalah deskriptif. Metode deskriptif adalah suatu metode dalam meneliti status sekelompok manusia, suatu objek, suatu set kondisi, suatu sistem pemikiran, ataupun suatu kelas peristiwa pada masa sekarang. Penelitian deskriptif hanya memaparkan suatu situasi atau peristiwa. Penelitian ini tidak mencari suatu hubungan, tidak menguji hipotesis atau membuat prediksi (Ardianto, 2011).

Artikel deskriptif mempelajari masalah-masalah dalam masyarakat serta tata cara yang berlaku dalam masyarakat serta situasi-situasi tertentu, termasuk tentang kegiatan - kegiatan, sikapsikap, pandangan-pandangan, sertaproses-proses yang sedang berlangsung. Adakalanya peneliti mengadakan klasifikasi, serta penelitian terhadap fenomena-fenomena dengan menetapkan suatu standar atau suatu landasan tertentu (Nazir, 2006). Dalam penelitian deskriptif, peneliti mendeskripsikan suatu fenomena dengan mengeksplorasi dan memberikan gambaran lengkap yang berkaitan dengan masalah dan fenomena yang diteliti. Penelitian deskriptif dilakukan untuk menggambarkan secara sistematis mengenai objek dan subjek yang diteliti.

Peneliti terjun langsung ke Kabupaten Bandung Barat dan melakukan wawancara dengan pihakpihak yang memahami aktivitas Corporate Social Responsibility, baik dari sektor pemerintah maupun perusahaan. Adapun kriteria narasumber adalah sebagai berikut:

1. Memahami kebijakan aktivitas Corporate Social Responsibility di Kabupaten Bandung Barat.

2. Memahami sinergitas yang sudah di bangun antara pemerintah dan perusahaan dalam aktivitas Corporate Social Responsibility di Kabupaten Bandung Barat.

Berdasarkan kriteria tersebut, peneliti melakukan wawancara kepada beberapa narasumber berikut ini:

1. Ibu Neneng, Asisten Sekretaris Daerah Bidang Perekonomian dan Pembangunan Kabupaten Bandung Barat

2. Ketua Forum Corporate Social Responsibility di Kabupaten Bandung Barat

3. Manajer Corporate Social Responsibility Badan Pengelola Waduk Cirata

Dari narasumber tersebut, peneliti membuat deskripsi secara sistematis, faktual, dan akurat tentang sinergitas pemerintah dan perusahaan dalam menjalankan aktivitas Corporate Social Responsibility serta kendala atau hambatan yang dihadapi oleh kedua belah pihak.

Selanjutnya, peneliti menggambarkan, meringkaskan berbagai kondisi, berbagai situasi, atau berbagai fenomena realitas sosial yang ada di masyarakat yang menjadi objek penelitian, dan berupaya menarik realitas itu ke permukaan sebagai suatu ciri, karakter, sifat, model, tanda, atau gambaran tentang kondisi, situasi, ataupun fenomena tertentu (Bungin, 2007). Jangkauan waktu dalam penelitian deskriptif adalah waktu sekarang atau sekurang - kurangnya jangka waktu yang masih terjangkau dalam ingatan informan.

Kerja peneliti dapat berupa menerangkan hubungan atau dapat pula memberikan gambaran - gambaran serta prediksi dan mendapatkan makna dan implikasi terhadap fenomena fenomena atau situasi dan keadaan yang ingin dipecahkan. Dalam mengumpulkan data, peneliti kerap menggunakan teknik wawancara dengan menggunakan pedoman wawancara (Nazir, 2006). Dalam penelitian deksriptif, peneliti berusaha menggambarkan dan menginterpretasi objek sesuai dengan keadaan yang terjadi.

Metode deskriptif ini bertujuan untuk membuat deskripsi secara sistematis, faktual, dan akurat tentang fakta - fakta dan sifat - sifat populasi atau objek tertentu (Kriyantono, 2011). Peneliti harus menjelaskan secara rinci mengenai objek penelitiannya dan menjelaskan proses pengumpulan datanya. Adapun penelitian 
deskriptif dilakukan untuk berbagai macam tujuan, diantaranya:

(1) Mengumpulkan informasi aktual secara rinci yang melukiskan gejala - gejala yang ada. (2) Mengidentifikasi masalah atau memeriksa kondisi dan praktek - praktek yang berlaku. (3) Membuat perbandingan atau evaluasi terhadap suatu program atau fenomena tertentu. (4) Menentukan apa yang dilakukan orang lain dalam menghadapi masalah yang sama dan belajar dari pengalaman mereka untuk menetapkan rencana dan keputusan pada waktu yang akan datang (Rakhmat, 2007).

\section{PEMBAHASAN \\ Sinergi Pemerintah dan Perusahaan Pada Kegiatan Corporate Social Responsibility}

Tahun 2007 pemerintah mengeluarkan Undang-Undang No 40 tahun 2007 tentang Perseroan Terbatas yang wajib untuk melaksanakan kegiatan Corporate Social Responsibility. Tentu saja keputusan pemerintah ini menuai protes. Protes ini mengemuka karena CSR merupakan kegiatan atau aktivitas yang berdasarkan pada kerelaan, tetapi dengan adanya UU tersebut CSR seperti dipaksakan. Cikal bakal munculnya CSR diawali dengan rasa filantropis, artinya adalah kegiatan sosial yang lebih bersifat charity atau bagi-bagi hadiah pada saat-saat tertentu. Aktivitas ini sama dengan sinterklas yang memberikan hadiah kepada anak-anak menjelang hari raya Natal. Akan tetapi, tingkat kritisnya masyarakat sehingga kegiatan CSR ini terus berkembang sebagai bagian dari izin untuk menjalankan operasi perusahaan di daerah setempat.

Tingkat kekritisan masyarakat ini ditunjang karena banyaknya aliran informasi yang mereka dapatkan. Informasi ini cepat berkembang dan cepat diterima karena perkembangan teknologi yang sangat pesat sehingga hal ini mendorong perubahan, cara berpikir, gaya hidup, dan tuntutan masyarakat yang semakin tajam. Selain kritisnya masyarakat, CSR berkembang karena adanya beberapa faktor, di antaranya adalah karena perubahan iklim, desakan dari media, dan stakeholder, kesehatan lingkungan atau kita mengenalnya dengan Tripple Bottom Up (People, Planet, dan Profit).

Adapun Tujuan Corporate Social Resposibiliy adalah: Pertama, membantu meningkatkan kualitas kesejahteraan komunitas, khususnya komunitas lokal yang berada di sekitar operasi wilayah perusahaan sehingga terjadi hubungan yang harmonis antara keduanya. Kedua, menciptakan sinergitas komunikasi dua arah yang efektif dengan stakeholder, terutama komunitas, dengan tujuan situasi dan kondisi yang kondusif bagi kelancaran operasional perusahaan. Ketiga, mengembangkan kegiatan Corporate Social Responsibility yang mengarah pada upaya pembangunan yang berkelanjutan dan menunjang core bisnis perusahaan. Keempat, menjaga dan menciptakan citra dan reputasi perusahaan yang positif sebagai perusahaan yang peduli pada kondisi komunitas, (Untung, 2008).

Riset yang dilakukan oleh Roper Search Worldwide menunjukkan 75\% responden memberikan nilai lebih kepada produk dan jasa yang dipasarkan oleh perusahaan yang memberikan kontribusi nyata kepada komunitas melalui program pengembangannya. Sekitar 66\% responden juga menunjukan bahwa mereka siap berganti merek kepada merek perusahaan yang memiliki citra sosial yang positif. Hal ini menunjukkan terjadinya perluasan minat konsumen dari produk menuju korporat (Susanto, 2002;2). Beberapa temuan mengapa perusahaan sangat sulit melakukan aktivitas CSR karena seringkali dipahami bahwa kegiatan CSR memerlukan dana yang melimpah, maka CSR ini pula identik dengan perusahaan-perusahaan besar saja.

Fakta pahit lainnya tentang aktivitas CSR adalah bahwa aktivitas CSR dilakukan oleh perusahaan hanya untuk menutupi kesalahankesalahan yang diperbuat oleh perusahaan terhadap lingkungan sekitar. Menurut Suhandari M Putri dalam Harian Umum Kompas, CSR adalah komitmen perusahaan atau dunia bisnis untuk berkontribusi dalam pengembangan ekonomi yang berkelanjutan, dengan memperhatikan tanggung jawab sosial perusahaan dan menitikberatkan pada 
keseimbangan antara perhatian terhadap aspek ekonomis, sosial, dan lingkungan. Susanto (2009) mengelompokkan realisasi program CSR dalam tiga bagian :

(1) Korporasi yang menjalankan CSR sebagai bentuk belas kasihan atau social obligation. (2) Korporasi yang menjalankan CSR sebagai bentuk social reaction atau tekanan eksternal (externally driven). (3) Korporasi yang telah mampu melakukan social response yang lahir karena ketulusan untuk memberikan kontribusi atau dorongan dari dalam (internally driven) demi kepentingan empowerment sosial.

MenurutYuningsih(2004), Tanggungjawab sosial perusahaan/lembaga baik pemerintah maupun swasta, atau dikenal dengan istilah CSR adalah kewajiban untuk membangun dan membantu masyarakat di mana perusahaan/ lembaga tersebut berada. Kesenjangan antara si kaya dengan si miskin, ketidakberdayaan pemerintah untuk menangani masalah sosial - ekonomi masyarakatnya, peningkatan daya kritis dan kontrol sosial masyarakat, tuntutan akan transparansi, dan harapan-harapan. Sebagai respon atas pengembangan CSR sebagai kegiatan yang berkelanjutan dan demi kepentingan empowerment social.

Kabupaten Bandung Barat telah memiliki Forum Bandung Barat CSR. Hal ini sebagai salah satu bentuk upaya sinergitas antara pemerintah dengan perusahaan di wilayah Kabupaten Bandung Barat. Sejarah lahirnya Forum Bandung Barat CSR (FBBCSR) di awali dari hotel manson Pine kota Baru Parahiyangan, berkumpul perwakilan perusahaan - perusahaan yang ada di Kabupaten Bandung Barat dan pejabat dari Satuan Kerja Perangkat Daerah (SKPD) melaksanakana kegiatan pengukuhan FBBCSR.

Menurut Asda Perekonomian KBB, latar belakang adanya FBBCSR adalah membangun sinergi antara pemerintah daerah dan perusahaan yang ada di KBB untuk membantu masyarakat secara tepat sasaran dan dapat dipertanggung jawabkan sehingga dengan adanya FBBCSR pembangunan kesejahteraan dilaksanakan secara berkelanjutan. Kabupaten Bandung Barat adalah kabupaten yang relatif muda namun memiliki semangat tinggi membangun ekonomi, terlihat dari perkembangan pencapaian pembangunan sampai akhir tahun ini. FBBCSR merupakan lembaga khusus yang terdiri dari perwakilan perusahaan, akademisi dan pemerintah kegiatan dari forum ini difokuskan kepada kegiatan penyediaan air bersih, sarana pendidikan, beasiswa, sarana kesehatan, rumah ibadah, infrastruktur, dan pembangunan kapasitas meliputi pendidikan wirausaha dan pemberian modal usaha, dalam forum ini dana yang sudah dikelola sebesar 1.26 milyar.

\begin{abstract}
Menurut ketua FBBCSR, kegiatan CSR yang telah dilakukan bersama-sama meliputi: membina kegiatan bersama berupa koperasi maju, mengolah limbah plastik yang masuk ke Bendungan Saguling, membantu menyiapkan peralatan yang mendukung pengelolaan limbah, memberikan bantuan kemitraan bina lingkungan, dan lain sebagainya. Forum CSR ini diharapkan dapat menurunkan angka kemiskinan dan merupakan wadah untuk menjaga komunikasi dan silahturahmi dunia usaha dengan pemerintah sehingga terjalin keserasian.
\end{abstract}

Menurut Rahmatullah (2013), letak keunggulan Forum CSR adalah sinergi antara Visi/ Prioritas Program Pemerintah dan Visi CSR Perusahaan, yang kemudian dunia usaha men-support program - program pemerintah yang sejalan dengan program CSR perusahaan. Karena bagaimanapun ada kesamaan fokus antara pemerintah maupun dunia usaha dalam prioritas programnya, yaitu tidak lepas dari isu: penanggulangan kemiskinan, pengangguran, kesehatan, pendidikan, dan pengembangan ekonomi. Dalam melaksanakan aktivitasnya, Forum CSR memiliki tugas - tugas, di antaranya:

1. Melakukan edukasi dan sosialisasi CSR.

2. Melayani dan memfasilitasi perusahaan untuk mengaktualisasikan CSR.

3. Mendata, mencatat, mendokumentasikan, dan publikasi seluruh kegiatan CSR yang dilakukan perusahaan.

4. Melakukan mediasi/konsultasi yang diperlukan perusahaan dalam implementasi CSR.

5. Memberikan apresiasi/penghargaan terhadap perusahaan yang telah menjalankan CSR secara nyata dan efektif serta memberikan kontribusi terhadap peningkatan kesejahteraan masyarakat. 
Jika sinergi antara pemerintah dan dunia usaha berjalan lancar melalui Forum CSR, maka besar kemungkinan ada akselerasi dalam pencapaian peningkatan kesejahteraan masyarakat pada satu wilayah.

Terkait pentingnya tanggungjawab sosial perusahaan dalam mendukung program pemerintah, dikemukakan oleh Supranoto (2007), bahwa: CSR memiliki pengaruh yang luas dalam membantu pemerintah meringankan upaya penanggulangan kemiskinan, serta peningkatan kesejahteraan masyarakat. Alokasi dana pemerintah untuk penanggulangan kemiskinan masih terbatas, dengan kondisi tersebut memerlukan dukungan dan keterlibatan aktif dunia usaha. Kegiatan CSR tentunya dapat membidik kelompok masyarakat yang belum tersentuh program penanggulangan kemiskinan, sehingga kualitas hidup yang lebih baik dapat dirasakan masyarakat secara merata. Dengan demikian, dalam kegiatan CSR ini seyogyanya perusahaan dan pemerintah mengajak masyarakat berpartisipasi secara aktif dan melibatkan seluruh lapisan masyarakat dalam setiap kegiatan pengembangan yang dicanangkan bersama antara pengelola dan masyarakat (Sudarmadji E Darmanto, 2014).

Diperlukan komitmen dalam bentuk kemitraan antarstakeholders agar terwujud CSR yang terintegrasi, khususnya antara pemerintah dan perusahaan. Sebagaimana diungkapkan Tenyson dalam Utama (2010), kemitraan merupakan kesepakatan antar sektor dimana individu, kelompok atau organisasi sepakat bekerjasama untuk memenuhi sebuah kewajiban atau melaksanakan kegiatan tertentu, bersama - sama menanggung risiko maupun keuntungan dan secara berkala meninjau kembali hubungan kerjasama. Dalam proses kemitraan, terdapat prinsip dasar yang harus dilaksanakan, sebagaimana dikemukakan Wibisono (2007), prinsip dalam proses kemitraan, meliputi: Pertama, kesetaraan atau keseimbangan (equity). Pendekatannya bukan top down atau bottom up, bukanjuga berdasarkan kekuasaan semata, tetapi hubungan yang saling menghormati, saling menghargai dan saling percaya. Kedua, Transparansi, hal ini diperlukan untuk menghindari rasa saling curiga antar mitra kerja. Ketiga, saling menguntungkan, suatu kemitraan harus membawa manfaat bagi semua pihak yang terlibat.
Dalam implementasinya, kemitraan yang dijalankan tidak selamanya ideal karena terkadang didasarkan pada kepentingan pihak yang bermitra. Menurut Wibisono (2007), Kemitraan yang dilakukan antara perusahaan dengan pemerintah maupun komunitas/ masyarakat dapat mengarah pada tiga sekenario, di antaranya:

Pola kemitraan kontra produktif. Hal ini terjadi jika perusahaan masih berpijak pada pola konvensional, hanya mengutamakan kepentingan shareholders atau mengejar profit sebesarbesarnya; Pola Kemitraan Semi produktif. Pemerintah dan komunitas atau masyarakat dianggap sebagai obyek dan masalah diluar perusahaan; Pola Kemitraan Produktif, Menempatkan mitra sebagai subyek, dan terlaksananya simbiosis mutualisme, perusahaan mempunyai kepedulian sosial dan lingkungan yang tinggi, pemerintah memberikan iklim yang kondusif bagi dunia usaha dan masyarakat memberikan dukungan positif kepada perusahaan.

Sinergi atau kemitraan antara pemerintah Kabupaten Bandung Barat dan Perusahaan mengalami pasang surut, tantangan yang nyata adalah bagaimana mereduksi prasangka atau ketidakpercayaan. Dari perspektif pemerintah Kabupaten Bandung Barat alasan membangun forum CSR adalah untuk mengurangi kebocoran anggaran yang digunakan untuk kegiatan yang sama, maksudnya adalah kegiatan atau program tersebut telah didanai atau dilaksanakan oleh perusahaan kepada masyarakat. Dalam CSR sesunguhnya pemerintah memiliki kepentingan dalam implementasi Corporate Social Responsibility, seperti yang diungkapkan oleh Steurer (2009) memberikan beberapa alasan mengapa pemerintah memiliki kepentingan di dalam isu Corporate Social Responsibility.

Pertama, hal tersebut sejalan dengan konsep pembangunan berkelanjutan (sustainable development). Motivasi pertama ini berkaitan dengan politik luar negeri seperti program pengembangan sumber daya manusia (human development program). Kedua, kebijakan CSR dianggap sebagai pelengkap yang menarik dalam peraturan yang lain misal di Indonesia dalam undang - undang Perseroan Terbatas, dalam hal ini pemerintah dapat menunjukkan 
kepeduliaanya pada isu sosial dan lingkungan meskipun peraturan tentang tanggung jawab sosial perusahaan ini hanya mendapatkan porsi yang sangat sedikit didalam undang- undang tersebut. Ketiga, pelaksanaan CSR masih sebatas pada asas sukarela (voluntary basis) sehingga pemerintah perlu memberikan penekanan agar pelaksanaan CSR lebih mendapat fokus perhatian dari perusahaan. Keempat, banyak pendekatan dalam pelaksanaan CSR menggunakan konsep partnership program (program kemitraan) sehingga akan membuka potensi keterlibatan masyarakat secara luas dalam pembangunan berkelanjutan. Hal ini sangat berkaitan dengan pengelolaan hubungan dan peran dengan pemangku kepentingan secara luas misalnya bisnis, pemerintah, dan masyarakat sipil.

\section{Komunikasi dan Corporate Social Responsibility}

Menurut Freeman dan Hasnaoui (2011) dalam Anuar, Amiruddin, Hafied, Wahyu (2015), Komunikasi merupakan salah satu bidang yang dikaji dalam Corporate Social Responsibility. CSR telah dibedah menjadi banyak komponen oleh banyak penulis, masing - masing dengan agenda yang berbeda. Hal ini termasuk istilah inklusif seperti tanggung jawab perusahaan, corporate citizenship, keberlanjutan, dan kinerja sosial perusahaan.

Komunikasi menjadi titik perhatian bagi tim Forum CSR di Kabupaten Bandung Barat, hal ini dikarenakan ditemukan beberapa persoalan terkait implementasi aktivitas CSR di Kabupaten Bandung Barat oleh perusahaan, seperti tidak adanya laporan data pelaksanaan CSR kepada pemerintah. Padahal Menurut tim Forum CSR Kabupaten Bandung Barat telah banyak yang dilakukan oleh perusahaan dan hal ini pun diakui oleh masyarakat bahwa pihak perusahaan telah memberikan banyak hal bagi perkembangan kesejahteraan masyarakat. Hanya yang menjadi catatan penting adalah belum adanya komunikasi yang baik antara perusahaan dengan aparat pemerintah. Pihak perusahaan lebih banyak berkomunikasi dengan Pokja. Menurut tokoh masyarakat yang kami wawancara bahwa banyak pokja diisi oleh kalangan tertentu (tokoh informal) sehingga aktivitas CSR dianggap sebuah proyek bagi pokja.

Kendalanya adalah masyarakat tidak sepenuhnya mengetahui aktivitas tersebut dan sering kali tidak tepat sasaran. Sesungguhnya penggunaan pokja sangat baik, apabila pokjapokja diisi oleh berbagai lapisan masyarakat baik tokoh formal maupun tokoh nonformal, dengan kata lain menurut Suherman (2004), perlu adanya kolaborasi tripartit, tripartit dimaksud terdiri atas pemerintah, pengusaha (dunia usaha), dan komunitas. Ketiga unsur ini paling berperan untuk menghidupkan dan menggairahkan perekonomian daerah, sehingga pada gilirannya kelak daya beli masyarakat (komunitas) akan meningkat karena jumlah pengangguran turun. Penggerakan ekonomi masyarakat membutuhkan inovasi dan terobosan baru. Oleh sebab itu, Ketua Dewan Juri Rekor Bisnis Eliezer Hernawan (2014), mengatakan agar perusahaan diharapkan terus memacu diri, mengembangkan perusahaan melalui inovasi dan terobosan-terobosan baru, serta siap bersaing dalam era pasar bebas ASEAN, termasuk melakukan bina lingkungan komunikasi. Sebagai gambaran bina lingkungan komunikasi, dapat dilihat di gambar di bawah ini:

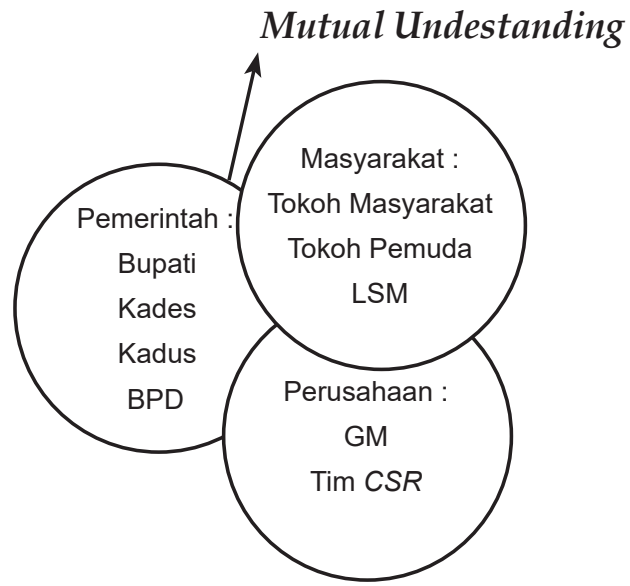

Gambar 1 Model Komunikasi Corporate Social Responsibility Sumber : Prastowo (2014)

Mengacu pada gambar 1 tersebut, pihak perusahaan dirasa perlu untuk mengembangkan aktivitas komunikasi dalam 
bentuk komunikasi CSR dengan pemerintah dan komunitas. Menurut prastowo (2014), aktivitas komunikasi ini perlu dilakukan untuk mencegah terjadinya kesalahpahaman atau double activity, seperti yang selama ini telah terjadi. Oleh karena itu, perusahaan harus mampu menempatkan diri dalam posisi yang sejajar dengan masyarakat binaan karena jika dirasa adanya pemaksaan kekuasaan dari perusahaan kepada masyarakat, maka akan menimbulkan dampak resistensi (Lutfi, 2012).

Proses komunikasi CSR bermanfaat untuk mempererat tali silahturahmi antara perusahaan dengan pemerintah, serta dapat digunakan sebagai langkah monitoring maupun fungsi radar bagi perusahaan demi kelancaran operasi perusahaan. Adanya komunikasi dua arah yang tercipta melalui bina lingkungan komunikasi dapat mempermudah kinerja tim CSR perusahaan sehingga visi dan misi perusahaan akan tercapai. Aktivitas komunikasi CSR dapat dilakukan secara formal maupun nonformal misalnya dengan rapat rutin bulanan, penyelenggaraan acara - acara keagamaan, gathering, dan peninjauan lokasi.

\section{SIMPULAN}

Pemerintah dan perusahaan di wilayah Kabupaten Bandung Barat telah membangun sinergitas dalam implementasi program program tanggung jawab sosial perusahaan, hal ini didasari oleh semangat kebersamaan dalam mengembangkan potensi sumber daya manusia maupun infrastruktur. Wujud nyata dari sinergitas tersebut adalah dengan dibentuknya forum CSR Kabupaten Bandung Barat. Dalam pelaksanaannya, antara pemerintah dan perusahaan masih terdapat kendala komunikasi. Komunikasi menjadi titik perhatian bagi tim Forum Corporate Social Responsibility di Kabupaten Bandung Barat, karena ditemukan beberapa persoalan terkait implementasi aktivitas Corporate Social Responsibility di Kabupaten Bandung Barat. Perusahaan tidak bersedia menyusun laporan pelaksanaan Corporate Social Responsibility kepada pemerintah. Oleh karena itu, perlu dibangun model komunikasi yang tepat antara pemerintah dan perusahaan sehingga akan tercipta pemikiran - pemikiran strategis, agar melahirkan masyarakat yang berdaya saing, mandiri, dan sejahtera. Model komunikasi yang tepat antara pemerintah, perusahaan, dan masyarakat Kabupaten Bandung Barat, yang disebut dengan tripartit corporate social responsibility perlu diperkuat, sehingga aktivitas CSR lebih terencana, tepat sasaran, dan berkelanjutan. Sinergi antara pemerintah dan dunia usaha harus dibangun melalui Forum CSR, maka besar kemungkinan ada akselerasi dalam pencapaian peningkatan kesejahteraan masyarakat di Kabupaten Bandung Barat.

\section{DAFTAR PUSTAKA}

Ardianto, E. (2010). Metode Penelitian Untuk Public Relations Kuantitatif Dan Kualitatif. Bandung: Simbiosa Rekatama Media.

Baskin, O., Aronoff, C., dan Latimore, D. (1996). Public Relations: The Profesion and The Practise. Brown and Benchmark Publisher.

Bungin, B. (2009). Metode Penelitian Kuantitatif, Komunikasi, Ekonomi, dan kebijakan Publik serta Ilmu - ilmu sosisal lainnya. Jakarta: Kencana.

Cahyati,W. (2008). Implementasi "Corporate Social Responsibility" dalam Pembentukan Citra PT Pertamina UP III Bandung. Jurnal Sosial dan Pembangunan, MIMBAR Unisba. Vol. XXIV No. 2 Hal 165 sd 176.

Cutlip, S. M., Center, A. H. and Broom, G. M. (2000). Effective Public Relations. New Jersey: Prentice Hall Inc.

DeFleur, M. L \& Dennis E. E. (1988).Understanding Mass Communications. Boston.

Hernawan, E. (2014) https://nasional. sindonews.com/read/927270/149/ hadapi-mea-dunia-usaha-harusjenius-1416549342.

Iriantara, Y. (2004).Community Relatios: Konsep dan Aplikasinya. Bandung: Penerbit PT Remaja Rosdakarya.

Indrawati, D. R., Awang, S. A., Faida, L. R., \& Maryudi, A. (2016). Pemberdayaan 
Masyarakat Dalam Pengelolaan DAS Mikro. Kawistara, 6(2), 113-224.

Irawan, D., \& Venus, A. (2016). Pengaruh Iklim Komunikasi Organisasi Terhadap Kinerja Pegawai Kantor Keluarga Berencana. Jurnal Kajian Komunikasi, 4/2, 122-132.

Isnaini,N.(2015).http:/ / fisip.ui.ac.id/mappingcorporate-social-responsibilitygovernance-in-asean-countries/.

Kriyantono, R. (2006).Teknik Praktis Riset Komunikasi. Jakarta: Kencana.

Lestari, S. Y., Komariah, N., \& Rizal, E. (2016). Pengelolaan Informasi Sebagai Upaya Memenuhi Kebutuhan Informasi Masyarakat. Jurnal Kajian Informasi \& Perpustakaan, 4(1), 59-68.

Lutfi, A. (2012). Lingkar kuasa kehidupan komunitas pemulung Pandesari Kota Malang. Jurnal Kawistara, 2/2.

Nazir, M. (2009). Metode Penelitian. Jakarta: Ghalia Indonesia.

Nugroho, D. R., Hubeis, A. V. S., Saleh, A. Priatna, W. B. (2016). Model of Communication Program Corporate Social Responsibility for Empowerment Community. Jurnal Sosial dan Pembangunan, MIMBAR Unisba. Vol 32 No 2 Hal 120 sd 131.

Prastowo, A.(2014). Pemetaan Karakteristik Sosial dan Budaya Masyarakat Desa X. Jurnal Komunikasi UNTAR. Vol 6 No 2 Hal 21 sd 33.

Rakhmat, J. (1985). Metode Penelitian Komunikasi. Bandung: Remadja Karya.

Rasyid, A. (2015). Komunikasi dalam CSR Perusahaan: Pemberdayaan Masyarakat dan Membangun Citra Positif. Jurnal Sosial dan Pembangunan MIMBAR Unisba. Vol. 31 No. 2 Hal 507 sd 518.

Sudarmadji, \& Darmanto, D. (2014). Dampak lingkungan dan risiko bencana pengembangan desa wisata studi kasus di desa wisata sambi. Jurnal Kawistara, 4(2), 129-141.
Sudaryoko (2015) http://surabaya.tribunnews. com/24/02/2015/hadapi-mea -30persen-csr-pt-phe-wmo-untukpendidikan.

Susanto, A.B.(2009). Reputation-Driven Corporate Social Responsibility. Jakarta. Esensi.

Supranoto.(2007). Seтua Untung. Majalah Bisnis dan CSR.

Suherman, M. (2006). Peranan Corporate Sosial Responsibility (CSR) dalam Menurunkan Angka Kemiskinan di Jawa Barat. Jurnal Sosial dan Pembangunan, MIMBAR Unisba. Volume XXII No. 3 Hal 317 sd 332.

Steurer,R. (2009). The role of governments incorporate social responsibility: characterising public policies on CSR in Europe. SpringerScience+ Business Media, LLC.

Triwardiantini, Y. (2015). http://market. bisnis.com / read / 20151028 / 192/486586/jelang-mea-korporasidituntut-terapkan - bisnis responsible.

Untung, H. (2008). Corporate Social Responsibility. Jakarta. Sinar Grafika.

Wiwitan, T., Trigartanti, Hernawati. (2008). Konsep Corporate Social Responsibility Dalam Kegiatan Community Relations. Jurnal Sosial dan Pembangunan, MIMBAR Unisba. Vol. XXIV No. 2 Hal 151 sd 164.

Wibisono,Y.(2007).Membedah Konsep dan Aplikasi CSR. Gresik. Fascho Publishing.

Yulianita, N. (2005). Corporate Sosial Responsibility Sebagai Aktivitas Social Marketing Public Relations. Jurnal Sosial dan Pembangunan, MIMBAR Unisba.Vol 9 No 1 Hal 123 sd 134.

Yuningsih, A. (2006). Peran Strategis Profesi Public Relations dalam Membangun Kemitraan Berbasis Nilai Spiritual. Jurnal Sosial dan Pembangunan, MIMBAR Unisba. Volume XXII No. 4 Hal 496-520. 